\title{
Dance and Dissidence in Wole Soyinka's Plays: From Status Quo to Revolution
}

\section{Inés Bigot}

\section{(2) OpenEdition}

1 Journals

Electronic version

URL: https://journals.openedition.org/ces/609

DOI: 10.4000/ces.609

ISSN: 2534-6695

Publisher

SEPC (Société d'études des pays du Commonwealth)

\section{Electronic reference}

Inés Bigot, "Dance and Dissidence in Wole Soyinka's Plays: From Status Quo to Revolution", Commonwealth Essays and Studies [Online], 42.1 | 2019, Online since 20 December 2019, connection on 22 September 2021. URL: http://journals.openedition.org/ces/609 ; DOI: https://doi.org/10.4000/ ces.609

This text was automatically generated on 22 September 2021.

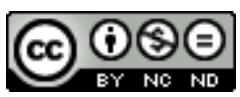

Commonwealth Essays and Studies is licensed under a Licence Creative Commons Attribution - Pas d'Utilisation Commerciale - Pas de Modification 4.0 International. 


\title{
Dance and Dissidence in Wole Soyinka's Plays: From Status Quo to Revolution
}

\author{
Inés Bigot
}

1 Wole Soyinka's works are not only marked by the cultural and psychological consequences of colonization, but also by the atmosphere of disillusionment and the situation of instability which characterized the post-independence period in Nigeria. Considering such a historical background, the medium of theatre was particularly suited to embarking on a double undertaking: allowing the regeneration of the Nigerian nation and triggering the awakening of the collective national consciousness which was a necessary step to call into question contemporary socio-political circumstances (Akporji 2003).

Chii Akporji, in her book, Figures in a Dance: The Theatre of W.B. Yeats and Wole Soyinka, notes that Soyinka is fully aware of the impact that a ritualized dramaturgy can have on the collective consciousness of colonial and postcolonial communities. Hence his association between a "ritual" kind of total theatre, exploring the creative and subversive potential of the dancing body, and the dynamics of spiritual regeneration and revolution. ${ }^{1}$ Indeed, Biodun Jeyifo reminds us that in Soyinka's essays on drama (in Myth, Literature and the African World and in some of his essays in Art, Dialogue and Outrage), ritual is seen as a "revitalizing and revolutionizing source for contemporary drama and theatre" $(2004,125)$.

3 It is precisely on the role of dance - understood as literary motif and performance within the context of a ritualized dramaturgy, that I intend to focus. As Helen Gilbert and Joanne Tompkins suggest, not only does dance, interpreted as a stylized spatial inscription, offer the opportunity to re-appropriate a territory which bears the mark of British imperialism, but it also corresponds to a non-verbal form of representation of the subject which is closely linked to the notion of empowerment (1996, 239-40).

4 In Soyinka's plays, dance is dual in the sense that it stands out both as the opposite of language - an unreachable oddity linked with the unspeakable, spiritual experience of 
the ritual trance - and as a strategic medium of expression which is conceived as a form of counter-discourse. Soyinka often turns the dancing body into a paradoxical discursive image which mediates a controlled, subversive message targeting the ideological constructs of power and authority. Suggesting that dance acts as a rebellious, disruptive discourse in some of Soyinka's plays does not imply that the specificity and autonomy of dance is being ignored in favour of a logocentric stance. Besides, the recurrent lack of detailed information as to the nature or the sequence of the dancers' movements and steps makes it difficult to reconstitute what Arnaud Rykner calls "a gestural grammar" ("une grammaire du geste") in L'envers du théâtre $(1996,190)$. However, dance, far from being reduced to the impulsive embodiment of an inarticulate feeling, is often presented as a powerful communicative medium, as a specific type of corporeal language which unites "showing" with "telling," the language of the dancer embodying its own content, which makes it even more powerful in terms of impact. ${ }^{2}$

5 There is no real contradiction between these two trajectories at work in Soyinka's plays (dance as an opaque, unspeakable moment and dance as a transgressive political statement) since, in both cases, the dancing characters epitomize resistance by refusing to be reduced to a passive "site of inscription," to borrow Susan A. Reed's words (1998, 527). This article will mainly focus on the second trajectory: dance as counterdiscourse.

6 The main targets of these dissident dancing bodies are numerous. They extend from colonial powers to the civil and military regimes which marked the postcolonial period starting with the independence of Nigeria in 1960, a key moment when Soyinka's "erstwhile 'comrades"' went back to Nigeria to "get a slice a of 'independence cake' and "step fast into the shoes of the departing whites before other people got there" (Soyinka 2002, XIII).

7 Thus, in Soyinka's plays, whether the dance is "macabre"3 or exemplifies a moment of pure joy, it is often seen as a metaphor for the redefinition of personal and communal identity, synonymous with the empowerment of the subject. Instead of being limited to a tool aiming at consensus, dance mediates the Nigerian playwright's dissident questioning of socio-political status quo. Bearing in mind the counter-discursive potential of dance, I will first show that dance is frequently presented as the symbol of "transition" and renewal in Soyinka's plays, laying particular emphasis on A Dance of the Forests. This will lead me to focus more specifically on various examples of the cohesive, revolutionary force that dance stands for in plays where the off-beat rhythm of rebellious bodies can wreak havoc on the imposed order of society, paving the way for a new dawn.

Dance is prevalent in Soyinka's total theatre ${ }^{4}$ plays which combine it with song, mime and language in a way that is reminiscent of Apidan theatre (traditional Yoruba theatre). ${ }^{5}$ Often symbolic of the moving body's inexhaustible power of resistance, it is associated with the notion of "transition" in plays such as A Dance of the Forests, The Road or Death and the King's Horseman. Let us recall Soyinka's lines to the producer in The Road: "The dance is the movement of transition" $(1973,149)$. Beyond the immediate ritual context of the cult of flesh dissolution $(\text { Agemo })^{6}$ to which Soyinka alludes here, this notion can be interpreted in broader socio-political terms, especially in a postcolonial context, and bearing in mind the fact that the concept of transition is 
often related, in Soyinka's essays, to the God of iron ${ }^{7}$ and creativity's powerful act of confronting the abyss of transition. ${ }^{8}$

In A Dance of the Forests, a play which was produced in 1960 as part of the celebrations for the independence of Nigeria, dance is linked to the necessary escape from intellectual paralysis and political status quo. It is seen as a critical test supposed to trigger an awakening of the Nigerian nation facing its new life. As Biodun Jeyifo explains in Wole Soyinka: Politics, Poetics and Postcolonialism, the central action of the play hinges round "a gathering of the tribes" $(2004,120)$ which is meant to "celebrate the glorious past and hopeful future" (121) of Africa but will eventually turn into a judicial confrontation with the "monstrous evils of the past and present life of the community" (121). Soyinka draws a parallel between this gathering of the tribes and the contemporary situation of Nigeria invested with the "historic task of forging a nation out of diverse peoples and communities which the celebrations symbolically entailed" (120).

10 Within this particular context the dance 9 in the forest, which is part and parcel of the "trial" condemning the infamous past of Africa, can be interpreted as a critical, initiatory and transitional moment when the human community (represented by three fallible characters, Demoke, Rola and Adenebi), the mirror of the newly independent Nigeria, chooses its future, symbolized by the half-child. ${ }^{10}$ The expiatory and inevitable dimension of the dance in the forest that occurs at the end of the play is underlined by Aroni (a forest dweller) in the prologue: "Forest Head, the one who we call oBANEJI, invited Demoke, Adenebi, and Rola to be present at the dance. They followed him, unwillingly, but they had no choice" (Soyinka 1973, 5). This idea of a compulsory step that needs to be taken in order to try and re-build the community on a democratic and peaceful basis is also present in the stage directions describing the "Dance of the Unwilling Sacrifice" which takes place in the village after Demoke has restored the half-child to his mother: "Dance of the Unwilling Sacrifice, in which Eshuoro ${ }^{11}$ and his Jester head Demoke relentlessly towards the totem and the silent dancing figures. Rola and Adenebi are made to sprinkle libation on the scene, continuously as in a trance" (72).

11 The reference to dawn breaking at the end of the play, along with the idea of a rite of purification undergone by Demoke and Rola, leave room for the possibility of some kind of regeneration despite the absence of a clear answer to Agboreko's question about the future of the community: "Does that mean something wise, child? [Sneaking up to Demoke.] Of the future, did you learn anything?" (Soyinka 1973, 74). In fact, Rola "looks chastened" (73) and Demoke mentions the "lightning that seared [them both] through the head" (74).

With hindsight, Forest Head's meditations have proved to be true: "The fooleries of beings whom I have fashioned closer to me weary and distress me. Yet I must persist, knowing that nothing is ever altered" (Soyinka 1973, 71). However, the historical events that took place in Nigeria a few years after independence (among which the Civil War, 1967-1970) must not lead us to underestimate the powerful potential of change which dance symbolizes in this play. Taking place at night, in the mysterious ritual space ${ }^{12}$ of the forest, the dance, which in Aroni's words was not "as dignified a Dance as it should be" (5), because of the vengeful presence of Eshuoro, goes beyond the "danse macabre" Soyinka talks about in the interview with Biodun Jeyifo. In that perspective, one has to bear in mind the fact that Eshuoro's presence was anticipated 
by Aroni, and this appears clearly in a dialogue that takes place between the latter and Forest Head:

FOREST HEAD: [...] Ah-Eshuoro?

ARONI: He will find us. I have laid a trail that will bring him to us.

FOREST HEAD: We will make use of him. If the child needs a fright, then the mother must summon the witch. (45-46)

It is indeed the threat Eshuoro represents that will ultimately lead to Demoke's choice of restoring the half-child to his mother. This is clearly perceptible in the stage directions that describe Eshuoro's attempt to control the half-child:

[...] When the Half-Child is totally disarmed by the Jester, Eshuoro picks him up suddenly and throws him towards the Third Triplet who makes to catch him on the point of two knives as in the dance of the child acrobats. Rola screams, the child is tossed up by the Third Triplet who again goes through the same motion, the other two Triplets continuing the furious 'ampe' round him and yelling at the top of their voices. Demoke, Rola and Adenebi again cluster together. The Half-Child is now tossed back to Eshuoro, and suddenly Demoke dashes forward to intercept. Eshuoro laughs, pretends to throw the child back [...]. They keep up this game for a brief period, with Demoke running between them, until Ogun appears behind the Interpreter, pulls him aside just as the child is thrown towards him, makes the catch himself passing it instantly to Demoke who has come running as before. All action stops again, including the first and second Triplets who have never ceased to 'ampe.' They all look at Demoke, who stands confused, not knowing what the next step should be. He decides eventually to restore the child to the Dead Woman [...]. (Soyinka 1973, 70-71)

In spite of the general atmosphere of violence, danger and death that prevails during the climactic scene of the play, ${ }^{13}$ the dance stands out as the eloquent medium used by Forest Head to "pierce the encrustations of soul-deadening habit" (71), the prerequisite for a possible change and revolution in the ways of thinking of the human community. Interestingly, in the 1960 production of the play, "the Dance for the HalfChild" - which takes a different form partly for technical reasons - contains a dance of the Ibos, called "an 'atilogwu'-ordered dance" in the stage directions, 'Atilogwu' meaning literally "putting in the medicine" (76) ${ }^{14}$ The potential therapeutic value of dance is underlined even more clearly, despite the fact that this dance is instigated by the Interpreter, Eshuoro's Jester.

Such a comparison between dance and renewal, dance and transition is also perceptible at the end of The Lion and the Jewel, which is characterized by a festive atmosphere: here, the dance, along with the song that accompanies it, amounts to the joyful celebration of Sidi and Baroka's marriage, to a fertility ritual. The child that is to be born through the union of a representative of the old world (Baroka) and a representative of the young generation (Sidi) becomes the symbol of the possible rebirth of this Yoruba village in the colonial period, and more generally speaking, of the Nigerian nation:

Festive air, fully pervasive. Oil lamps from the market multiply as traders desert their stalls to join them. A young girl flaunts her dancing buttocks at Lakunle and he rises to the bait [...]. Lakunle last seen, having freed himself of Sadiku, clearing a space in the crowd for the young girl.

The crowd repeat the song after Sidi.

Tolani tolani

T'emi ni T'emi ni

Sun mo mi, we mo mi

Sun mo mi, fa mo mi

Yarabi lo m'eyi t'o le d'omo. ${ }^{15}$ (Soyinka 1974, 57-58) 
In these lines, the cohesive potential of dance is perceptible, pointing the way to the creation of a new community and a new Lakunle shorn of his warped notion of modernity and knowledge. Thus, often taken as an agent of change and regeneration, the dancing body quickly becomes a threat to the imposed order, defying various forms of authority. In Soyinka's plays, dance, far from being considered as a frivolous pastime or virtuoso performance, is all the more conducive to rebellion as it is shown as a universal privilege and weapon. It is a means of expression that can be adopted by different members of society, from the traditional oba ("king") (Kongi's Harvest) to victims of the Civil War (such as Aafaa, the spastic "dancer" in Madmen and Specialists) and prisoners (in From Zia, With Love), not to forget apparently disempowered women (Sadiku's dance of victory in The Lion and the Jewel which celebrates Baroka's supposed loss of virility (1974, 30-31).

To choose but a few examples, Kongi's Harvest opens with the imprisoned, traditional king Oba Danlola and some of his followers' adoption of a counter-discourse which is channelled through song and dance. The characters thus voice their protest against the tyranny of the new leader of the nation, Kongi - an "epileptic" dictator - in what amounts to a "desecration" of the National Anthem in the Superintendent's words. Danlola's dance, which immediately follows the Superintendent's denunciation of "these antics" that do not befit an elder and a King, reasserts the Oba's authority as the stage direction indicates through the use of the adjective "royal": "to the beat of 'gbedu' drum, steps into slow, royal dance" $(1974,62)$. Here, dance acts as a reply to the Superintendent's criticism. The dance and the song thus go hand in hand in mediating a rebellious message which is thought to be more efficient than words alone. To illustrate this point, the following lines from the subversive song bear witness to the inadequacy of spoken language in front of the mechanical, repetitive discourse of power which stifles the expression of dissident opinions or arguments:

[...] Who but a lunatic

Will bandy words with boxes

With government rediffusion sets

Which talk and talk and never

Take a lone word in reply. [...]

I cannot counter words of

A rediffusion set [...]. (61-62)

In the context of this play, where dancing is associated with speaking one's mind, ${ }^{16}$ dance acts as a metaphor for and as the modus operandi of the struggle against the power of Kongi. ${ }^{17}$ The recurrent allusions to the dance that is to take place during the Festival of the New Yam where Kongi is supposed to receive the ritual tuber from Danlola's hands, point to the threat it represents for the established order. As Daodu explains to Oba Danlola in the second part of the play, "Kabiyesi, this is no time for trivialities. We shall all have our dance tonight, when it matters [...]" $(1974,112)$. In point of fact, the dance during which Kongi receives a copper salver containing the head of Segi's dissident father serves as a powerful counter-discourse to the leader's preceding praise of "the Spirit of Harvest" and the "spirit of resurgence" (129). Segi's decision to present this "season's gift to the Leader" (129) enables her to turn the frenzied bacchanal that was part and parcel of the "Harvest orgy of food and drink" (130) into a political statement which leaves Kongi "speechless," 18 as the stage directions indicate: 
The rhythm of pounding emerges triumphant, the dance grows frenzied. Above it all on the dais, Kongi, getting progressively inspired harangues his audience in words drowned in the bacchanal. He exhorts, declaims, reviles, cajoles, damns, curses, vilifies, excommunicates, execrates until he is a demonic mass of sweat and foam at the lips.

Segi returns, disappears into the area of pestles. A copper salver is raised suddenly high; it passes from hands to hands above the women's heads; they dance with it on their heads; it is thrown from one to the other until at last it reaches Kongi's table and Segi throws open the lid.

In it, the head of an old man.

In the ensuing scramble, no one is left but Kongi and the head, Kongi's mouth wide open in speechless terror. (131-32) ${ }^{19}$

As Eldred Jones argues in The Writing of Wole Soyinka, Kongi's Harvest is not only "the representation of a clash between a modern dictatorship and the traditional system which it has effectively replaced [...]. It is ultimately a representation of the clash between the life-giving forces and death-producing forces" $(1988,100)$.

Just as dance is chosen by Danlola, Segi and Daodu as a vehicle for protest in Kongi's Harvest, the dissident prisoners in From Zia, With Love break into a dance that embodies their potential for revolt, although it comes to a stop when the sick man collapses $(1999,105) .{ }^{20}$ Facing the limits of spoken language (since the Superintendent does not listen to his remarks about the disastrous health of the prisoners), Hyacinth resorts to "rhythm" as an inductive, cohesive and rebellious strength. The stage directions thus show the shift from sterile violence, as Hyacinth shakes the bars of the cell doors, to a creative rhythmic act which translates into a chant and a dance:

He changes the violent shake to a rhythmic one, and is soon joined in by the other prisoners who bang cups, plates, sticks and join in the chant [...]. Someone begins to stamp to the rhythm. In a few moments, the cell is filled with gyrating figures in silhouette, the corridor bulb leaving a pool of light forestage so that the sick man remains visible. (105)

Another striking example of the dancing body's ability to fight authority through the assertion of a dissident rhythm is Chume's dance in front of Major Silva, from the Salvation Army, in Jero's Metamorphosis. Chume, who cannot play the trumpet in response to Major Silva's request and who possesses a practical and natural relation to music in contrast with Silva who says he understands it, plays according to his own sensibility despite Silva's reproaches and attempt to control his tempo. Chume's aggressive dance, along with the traditional rhythm of the music he plays, appears as the climax of the struggle, as a re-assertion of his personal identity as a musician, and it succeeds in reverting the balance of power. The dance is understood as a threat by Major Silva, triggering his exit from the scene. ${ }^{21}$ Here are the stage directions which describe Chume's (momentary) but symbolic triumph:

Throws himself into the music now, turning the tune into a traditional beat and warming progressively. His legs begin to slice into the rhythm and before long his entire body is caught up with it. He dances aggressively towards Silva who backs away but cannot immediately escape as Chume's dance controls the exit [...]. (1974, 191-92)

Chume's musical and dancing style is all the more subversive as it deviates from what Silva earlier describes as the expected standards of the Salvation Army tune: “[...] Always remember that the tunes of the Army must be martial in colour and tempo. We march to it remember, not dance" (190). As we learn from Silva, the Salvation Army has "an important date at tomorrow's executions" (191). This is an allusion to the 
transformation of Lagos Bar Beach into a "National Public Execution Amphitheatre" which is meant to boost the tourist trade (Soyinka 1974, 201) - a "reference to the public execution of robbers, a phenomenon that has remained a postwar reality in this country" (Osofisan 1978, 160). Chume's "swingy beat" (Soyinka 1974, 189) and his spontaneous dance thus trample the disciplinary, military dimension of this kind of music underfoot.

This is all about putting forward one's own dissident rhythm, what Christiane Fioupou calls, quoting from Madmen and Specialists, the '“self-tickling' 'tick-tock' of the heretic pulsating against the beat of dogma" in "Le pouvoir sur scène : contorsions politicoreligieuses dans le thêâtre de Soyinka." ${ }^{22}$ In Madmen and Specialists, Aafaa, one of the victims of the Nigerian Civil War, ironically called "the dancer" (Soyinka 1974, 218) in the initial stage directions, invests his personal affliction, St-Vitus spasms, with an explosive dimension. Although Aafaa's "dance," a parody of traditional trance dance, is the result of a traumatic shock triggered by the atrocities of the war, the character turns it into a striking denunciation of the "manipulations to which men have been subjected at all levels." ${ }^{23}$

Thus, in Soyinka's plays, the art of Terpsichore either contributes to or celebrates the redefinition of the balance of power in society. The women's dance in Death and the King's Horseman (scene 3), indirectly compared to a "riot," is a case in point. Coming after the verbal fight with Sergeant Amusa and his men during which the women and the girls succeed in destabilizing these representatives of authority, it indicates the impulse to embody victory not only over the opposite sex but also over the colonial order that Amusa serves. ${ }^{24}$ The description of the dance illustrates the intensity of the moment as well as its intrinsic chaotic dimension: "A Woman bursts into song and dance of euphoria [...]. The rest of the Women join in, some placing the Girls on their back like infants, others dancing round them. The dance becomes general, mounting in excitement" (Soyinka $2009,42-43)$.

21 Such a communal impetus turns into a revolutionary force in Soyinka's creative adaptation of Euripides's The Bacchae entitled The Bacchae of Euripides, a Communion Rite, in which

the dancing returns the power of the past to the people, the power that Pentheus' cruel governance had denied them. All the different forms of dancing also image an end to the political and historical structures that empire had imposed on the region - both specifically in Nigeria and more widely throughout Africa - and which power-hungry rulers like Pentheus retained: dancing is liberation. Not only is Pentheus conquered, but other imperial manifestations of his rule are also banished when the dance's power takes effect. (Gilbert and Tompkins 1996, 40)

It is clear that the dancing followers of Dionysos are seen by the ruler Pentheus as agents of disorder: "I want an end to the drunken dancing / The filth, the orgies, the rot and creeping / Poison in the body of state. I want Order and - / I want immediate results [...]" (Soyinka 1973, 256). In this play where it simultaneously functions as the unspeakable experience of trance and as "cunning subversion" (257), dance is the symbol of revolution and of the "new order" that the Leader of the Slaves celebrates at the beginning of the play (239), an order which implies the death of Pentheus. ${ }^{25}$ Throughout the play, dance stands for a "new vitality" which is said to be "catching Thebes on the rebound" offering a way out of the "fossilized past" (252). As such, it produces a shift in the people's habits, disrupting the rules of propriety and transcending "the barrier of age, the barrier of sex or slave and master" (255). 
The reversal of the hierarchical basis of society is put forward in an eloquent scene in which Dionysos turns the strict, tyrannical, "militaristic" (Soyinka 1973, 293) leader Pentheus into a feminized Dionysian dancer: under the influence of wine, Pentheus does not realize that he has been dressed in women's clothes by the god ("a female Bacchic costume," 289). His movements which are supposed to be those of a military march actually amount to a dance which closely resembles Tiresias and Kadmos's own earlier dance (255):

PENTHEUS: He's taught [the drill-master] a new march to the household cavalry

A masterpiece of precision. We'll prance through

Thebes like those splendid horsemen. Wait,

I'll teach you the movements. It's simple-

Watch my feet!

[He draws his 'sword', performs a brief salute forwards and sideways, then strikes a dance

pose]

Here we go-

One-Two-Back, One-Two-Back, One-Two-Back...

[exactly like Tiresias. The music of Dionysos accompanies him, swelling in volume as Pentheus throws himself passionately into the dance, exhorting Dionysos's efforts.] (293)

The Bacchae of Euripides enables us to grasp the nature of the links existing between dance and revolution. When Tiresias tries to explain to Kadmos the "meaning of the dance," he develops the idea of a better understanding of oneself triggered by a previous process of purification which implies leaving preconceived ideas aside, a necessary step to produce durable changes in the ethos and the lives of the people of Thebes: "When you step into the dance you'll lose all your silly notions" (Soyinka 1973, 255).

23 As a medium that helps to create a "crack in the dead crust of the soul" (Soyinka 1973, 244) dance clearly acquires a potent subversive role in Wole Soyinka's plays where freedom and liberation from all kinds of constraints and fetters often translate into dancing feet treading the road of life. The dancing body - and more generally speaking the moving body's considerable power of re-creation of a personal and communal identity - easily turns into a rebellious weapon. Even in the plays where dance is interrupted or does not explicitly and immediately bear fruit, it conveys a hope for change as the dancers are pregnant with the embryo of an upcoming revolution. The dancing body, understood as agent and not simply as a passive "site of inscription," illustrates Jero's words in Jero's Metamorphosis, taken literally: "To survive, we need fullbodied tactics" (Soyinka 1974, 177).

\section{BIBLIOGRAPHY}

AKPORJI, Chii. 2003. Figures in a Dance: The Theater of W.B. Yeats and Wole Soyinka. Trenton: Africa World Press.

AJAYI, S. Omofolabo. 1998. Yoruba Dance. Trenton: Africa World Press. 
BIGOT, Inés. 2019. "De l'envers des mots au discours muet : danse et langage dans le théâtre de William Butler Yeats et de Wole Soyinka." Recherches en danse. "Focus." 12 July. https:// journals.openedition.org/danse/2075.

DAVIS, Ann B. 1980. "Dramatic Theory of Wole Soyinka." In Critical Perspectives on Wole Soyinka, edited by James Gibbs, 147-57. Washington: Three Continents Press.

ELLIS, Sylvia. 1999. The Plays of W.B. Yeats: Yeats and the Dancer. Basingstoke: Macmillan Press.

FIOUPOU, Christiane. 1989. "Le pouvoir sur scène : contorsions politico-religieuses dans le théâtre de Soyinka." "Rivages II." Special issue, Cahier d'études africaines 29: 115-16. http:// www.persee.fr/doc/cea_0008-0055_1989_num115_1634. FIOUPOU, Christiane. 1991. La route : réalité et représentation dans l'oeuvre de Wole Soyinka. Thèse de doctorat d'Etat. Montpellier. June. Published under the same title by Rodopi in 1994.

FRASER, Robert. 1979. "Four Alternative Endings to Wole Soyinka's A Dance of the Forests." Research in African Literatures 10, no. 3 (Winter): 359-74. http://www.jstor.org/stable/3818351 GILBERT, Helen, and Joanne TOMPKINS. 1996. Post-colonial Drama: Theory, Practice, Politics. London: Routledge.

GÖTRICK, Kacke. 1984. Apidan Theatre and Modern Drama: A Study in a Traditional Yoruba Theatre and Its Influence on Modern Drama by Yoruba Playwrights. Göteborg: Almqvist and Wiksell International. JEYIFO, Biodun. 2004. Wole Soyinka: Politics, Poetics and Postcolonialism. Cambridge: Cambridge University Press.

JONES, Eldred Durosimi. 1988. The Writing of Wole Soyinka. 1973. London: James Currey; Portsmouth: Heinemann.

OGUNBA, Oyin. 1975. The Movement of Transition: A Study of the Plays of Wole Soyinka. Ibadan: Ibadan University Press. 69-102.

OSOFISAN, Femi. 1978. "Tiger on Stage: Wole Soyinka and Nigerian Theatre." In Theatre in Africa, edited by Oyin Ogunba and Abiola Irele, 151-75. Ibadan: Ibadan University Press.

REED, Susan A. 1998. “The Politics and Poetics of Dance.” Annual Review of Anthropology 27. https:// www.jstor.org/stable/223381.

RYKNER, Arnaud. 1996. L'envers du théâtre : dramaturgie du silence de l'âge classique à Maeterlinck. Paris: José Corti.

SOYINKA, Wole. 1973. A Dance of the Forests (1963), The Road (1965), The Bacchae of Euripides (1973). Wole Soyinka: Collected Plays 1. Oxford: Oxford University Press.

SOYINKA, Wole. 1974. The Lion and the Jewel (1963), Kongi's Harvest (1967), Madmen and Specialists (1971), Jero's Metamorphosis (1973). Wole Soyinka: Collected Plays 2. Oxford: Oxford University Press (reprinted in 2009).

SOYINKA, Wole. 1993. "Between Self and System: The Artist in Search of Liberation." 1974. In Art, Dialogue, and Outrage, 45-47. New York: Pantheon Books.

SOYINKA, Wole. 1999. From Zia, With Love (1992). Wole Soyinka: Plays 2. London: Methuen Drama. SOYINKA, Wole. 2002. Introduction. Plays 1. London: Methuen Drama, X-XXI. Interview "Soyinka at 50" first published in 1984 in West Africa.

SOYINKA, Wole. 2005. Myth, Literature and the African World. 1976. Cambridge: Cambridge University Press. 
SOYINKA, Wole. 2009. Death and the King's Horseman. 1975. London: Bloomsbury Methuen Drama.

SOYINKA, Wole. 2012. Of Africa. New Haven: Yale University Press.

WALLART, Kerry-Jane. 2014. "Dépossessions : le rôle de la chorégraphie dans A Dance of the Forests et The Bacchae of Euripides de Wole Soyinka." Sillages Critiques 18. http://journals.openedition.org/ sillagescritiques/4098.

WILKINSON, Nick. 1980. “Demoke's Choice in Soyinka's A Dance of the Forests." In Critical Perspectives on Wole Soyinka, edited by James Gibbs, 69-73. Washington: Three Continents Press.

ZeNEnGa, Praise. 2015. "The Total Theatre Aesthetic Paradigm in African Theatre." In The Oxford Handbook of Dance and Theatre, edited by Nadine George-Graves, 236-49. Oxford: Oxford University Press.

\section{NOTES}

1. As Akporji notes, Soyinka "understood ritual to denote the communicative aspect of culturally defined sets of behaviour or customs, a much wider interpretation of the term than that by Aristotle or Nietzsche" $(2003,46)$. In her article "Dramatic Theory of Wole Soyinka," Ann B. Davis states that "essentially, Soyinka views ritual as that which drama incorporates to develop social

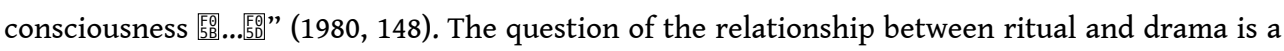
vexed one. While they can be compared, one has to take into consideration the difference between a sacred ritual, taken independently from its potential relationship with dramatic elements, and a ritual which takes place within the context of a specific play (Gilbert and Tompkins 1996, 59-61). Having said that, Wole Soyinka's plays often depart from a dramaturgy based on mimesis, opting for a strategy of presentation rather than mere representation which sometimes contributes to the blurring of the line between the efficacious dimension of the ritual and the fictional aspect of theatre (on the subject of ritual and drama, see Gotrick 1984, 14.)

2. These remarks on dance and language echo those developed in my article, "De l'envers des mots au discours muet: danse et langage dans le théâtre de W. B. Yeats et de Wole Soyinka" (Bigot 2019). Kerry-Jane Wallart underlines the ambiguous relationship between language and dance, arguing that in his plays, Soyinka explores the communicative "linguistic" potential of dance while calling it into question at the same time (2014). More generally, as Sylvia Ellis explains in The Plays of W.B. Yeats, the question "can dance be considered as a language?" is "a very old debate" $(1999,248)$. The links between dance and language have been addressed by many thinkers and writers from Plato (Book 7 of The Laws) to Thoinot Arbeau (Orchesography), Jean-Georges Noverre and Ann Hutchinson (with her work on Labanotation), to quote but a few of them. One can draw a parallel between dance and language which both constitute "symbolic systems," but it is a fact that dance does not share all the characteristics of language, among which Ellis mentions translatability and synonymity (248-50). My purpose here is not to prove that dance functions exactly as verbal language but to stress the peculiar communicative potential it is invested with in Wole Soyinka's plays, which do not relegate it to the sphere of asemantic impulses. For more information on the conception of dance as a "purveyor of meaning" in its own right (Ellis 1999, 248), and in a Nigerian context, see Omofolabo S. Ayaji's Yoruba Dance in which she defines dance as "an effective symbol of communication," whose richness lies in "the fact that it functions as a multi-dimensional phenomenon, codifying experience in several channels simultaneously" $(1998,22)$.

3. In an interview with Biodun Jeyifo, Soyinka defines his theatrical aesthetics in the following way: "It was then [when Nigeria became independent] that I began to write A Dance of the Forests, which takes a jaundiced view of the much vaunted glorious past of Africa. And I suppose since 
then I've been doing nothing but the danse macabre in this political jungle of ours" (Soyinka 2002, XIII).

4. In an article devoted to African total theatre, "The Total Theatre Aesthetic Paradigm in African Theatre," Praise Zenenga states that "in most African performance traditions and conventions, music, dance, drama, and other theatrical practices exist in a complex, complementary, and logical-dynamic system of performative expressions that are known as total theatre ${ }_{50}$... 媐.

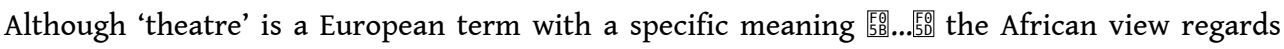
theatre as a broad practice and discipline that eludes narrow definition. Likewise, the African concept of total theatre is not restricted to scripted drama alone, but is a broad and inclusive practice that incorporates drama, dance, and music" (2015, 236-37). Zenenga also mentions Western total theatre, arguing that "although it is thought to have risen from Wagner's intention to produce a Gesamtkunstwerk or "total work of art," Artaud, Brecht, Piscator, Brook, and Schechner became the leading proponents of Western total theatre, whose radical politics and audience participatory techniques parallel African total theatre" (240).

5. On Apidan theatre, see Götrick 1984.

6. Agemo is described by Soyinka as "a religious cult of flesh dissolution" including "the passage of transition from the human to the divine essence" in his notes "For the Producer" $(1973,149)$. In The Road, Murano's masked dance which occurs at the end of the play completes the process of transition that had started during the Drivers' Festival before the character was knocked down by a lorry. For more on Agemo, see Fioupou 1991, 248-75.

7. "Ogun was the deity who forged the primal instrument that hacked through primordial chaos, blazing a path for the gods' reunion with man" (Soyinka 2012, 159).

8. Oyin Ogunba shows how Soyinka exposes the "crudities and sufferings of a society in a state of transition." The "'dance' between the Establishment and [...] reformers is what constitutes the essence of the movement of transition and it is the focus of Soyinka's dramatic art" $(1975,2)$.

9. The "dance" actually takes the form of three distinct dances in the last part of the play, the "ampe" dance, the "Dance for the Half-Child" and the final "Dance of the Unwilling Sacrifice." While the "ampe" ("a Yoruba children's dance" as Ogunba explains) is a "demonic," frantic one which seems to act as an "indication of the pattern of the community's movement towards selfdestruction" (Ogunba 1975, 92), the other two leave room for the possibility of action and positive change.

10. For more on the complex symbol of the half-child, see Jones, Wilkinson and Ogunba. Suffice it to say, following Ogunba, that this "monster child" $(1975,87)$ that had remained in his dead mother's womb for a very long time is eventually born thanks to Forest Head's divine order in the second part of the play (63).

11. Eshuoro, presented as "a wayward cult-spirit" in the stage directions, is driven by his will to avenge his desecrated tree which Demoke has carved in order to build a totem for the Gathering of the Tribes.

12. Here are the stage directions indicating the nature of the place where the climactic scene unfolds: "Back-scene lights up gradually to reveal a dark, wet atmosphere, dripping moisture, and soft, moist oil. A palm-tree sways at a low angle, broken but still alive. Seemingly lightningreduced stumps. Rotting wood all over the ground. A mound or two here and there. Footfalls are muffled. First, there is total stillness, emphasized by the sound of moisture dripping to the ground [...]" (60). In her doctoral thesis, Christiane Fioupou interprets such a place as the symbolic representation of the "chthonic realm": "This frightening scene clearly evokes the ritual space par excellence, the chthonic realm, 'the transitional yet inchoate matrix of death and becoming' [see Soyinka, Myth, Literature and the African World 142]. It is the place where masks, music and dances will be used intensively since they stand for the rite of passage, 'the movement of transition"' (Fioupou 316, my translation). 
13. The violent, death-like atmosphere of the "trial" scene is partly due to the negative, pessimistic (albeit visionary) words of the various spirits chorusing the future, followed by the presence of the monstrous Triplets interpreted by Eldred Jones as the "physical manifestations of the rhetorical distortions which are used to justify political crimes" $(1973,69)$.

14. On the subject of the 1960 production, see Robert Fraser's article in which he puts forward the difficulties engendered by the "dance of the child acrobats" as it unfolds in the original typescript and the published play, as well as the greater theatrical efficiency of the acting version (Fraser 1979). Eldred Jones underlines the dangerous nature of "the dance of the child acrobats": "This perilous dance, for which Soyinka had to substitute a different tableau in the alternative ending of the play, is done by professional dancers in many parts of West Africa" $(1988,69)$. Truly, in the 1960 production, the Third Triplet, the Interpreter and Eshuoro toss the "wood figure of an "ibeji" (a twin figurine which the Half-Child "has clutched from his first appearance") to one another instead of the Half-child himself.

15. The song is translated as follows: "Tolani Tolani / She belongs to me, belongs to me / Come close to me, wrap yourself around me / Only God knows which moments makes the child" (Soyinka 1974, 58).

16. In the second part of Kongi's Harvest, Sarumi utters the following words before starting to dance: "In Oba Danlola's place his sons / Speak out their minds. [Dances]" $(1974,110)$.

17. It is worth noting that most of the dissident characters of the play (Oba Danlola, Segi and Daodu) often dance, which helps us grasp the links between dance and power, dance and revolutionary potential.

18. This example of dance as counter-discourse is developed in my article "De l'envers des mots au discours muet" (Bigot 2019).

19. The play does not end with the striking image of speechless Kongi but with the "iron grating" which "descends and hits the ground with a loud, final clang" (Soyinka 1974, 138). Danlola and the Secretary's preceding conversation in the last part, "Hangover," suggests that the revolution started by Daodu and Segi may very well be interrupted by Kongi (133-38). Nonetheless, the strength and visual impact of Segi's political act lingers in the reader's and the audience's minds, pointing the way for possible future upheavals. As Ogunba puts it, if one considers it from "the point of view of pure theatrical effect," "Segi's presentation of a human head [...] to Kongi" is "the real end of the play, for it is this incident which stays permanently with the audience as the finale" $(1975,195)$.

20. From Zia, With Love is based on an event which took place in Lagos in April 1985 under the Buhari-Idiagbon regime, the execution of three drug traffickers by a military firing squad. See Jeyifo $(2004,111-12)$ for more details on the circumstances of the event. The play confronts us with the performance games of various prisoners who imitate in play the military leaders ruling Nigeria. Its interest lies in "Soyinka's mobilization of the visual, verbal, gestural repertoire of popular festivity and hilarity as sources of resistance to the authorized, decreed languages and culture of impunity of the state, the state of drunken power and pomp, of obsession with rank and authority 監.... [50" (Jeyifo 2004, 113-14).

21. See "De l'envers des mots au discours muet" (Bigot 2019).

22. Here is the original version: "Le 'doux tic tac de l'hérétique' battant à contretemps du dogme" (Fioupou 1989, 424). The English translations used here have been borrowed from Christiane Fioupou's own translation of her paper.

23. "Manipulations subies par l'homme à tous les niveaux" (Fioupou 1989, 420). Example used in "De l'envers des mots au discours muet" (Bigot 2019).

24. As Jane Plastow explains in the Bloomsbury Methuen edition of the play, Amusa is a "Native administration' policeman, that is, he is not employed by the British government but by the locally appointed leadership. This was the lowest form of police force in colonial Nigeria [...]. As one who fully inhabits neither the Yoruba not the white world, Amusa is generally seen as a 
white man's lackey who has sold his manhood to serve the colonists" (Death and the King's Horseman edited by Jane Plastow, XXXII-XXXIV).

25. Beyond the role of dance itself in the play, Soyinka's own words about The Bacchae of Euripides in "Between Self and System" give evidence of the intrinsic link existing between theatre and revolution: "Revolution, as idiom of the theatre and explication of Nature itself is, in my opinion, at the heart of The Bacchae of Euripides [...]. And perhaps it is because of the recognition of Dionysos as, on one level, a universal paradigm for the artist - the dramatic artist that is, as illusionist, conjurer, agent of release and control, a medium of primordial chaos, yet midwife of beginnings - that a celebration of Dionysos becomes, truthfully, a celebration of theatre: theatre as community, as idiom of liberation and renewal" (1993, 45-47).

\section{ABSTRACTS}

In Wole Soyinka's plays, dance reveals an open conception of African identity, namely a fluid, perpetually evolving one which leaves room for metamorphosis and change. As the symbol of transition, dance is often invested with revolutionary potential, pointing the way to a new dawn, out of an existential and political status quo. Embodying resistance and dissidence, the dancing bodies in Soyinka's plays contribute to the reconfiguration of individual and communal identity.

INDEX

Keywords: Soyinka (Wole), dancing body, renewal, regeneration, dissidence, counter-discourse

\section{AUTHOR}

\section{INÉS BIGOT}

Université Sorbonne Nouvelle - Paris 3

Inés Bigot is a third-year doctoral student working on a comparative study of the plays of W.B. Yeats and Wole Soyinka at the Sorbonne Nouvelle. Her current research focuses on the role of dance and the notions of resistance and dissidence in the two playwrights' dramatic corpus. 